\title{
Influence of Varying Concentrations of Ammonium Sulphate Foliar Spray on Phenology and Yield of Canola
}

\author{
*Muhammad Mehran Anjum, Nawab Ali, Muhammad Shafi, Muhammad Zahir Afridi, Muhammad Owais Iqbal \\ and Burhan uddin
}

Department of Agronomy Faculty of Crop Production Science, University of Agriculture, Pakistan

Submission: March 14, 2017; Published: April 24, 2017

*Corresponding author: *Muhammad Mehran Anjum, Department of Agronomy Faculty of Crop Production Science, University of Agriculture, Peshawar, Pakistan, Email: mehrananjum@aup.edu.pk

\begin{abstract}
There is usually a positive yield response when sulfur (S) is applied to rapeseed (Brassicarapa L.) plants grown on S-deficient soils. Canola, being a conventional oil seed and winter season crop that is grown successfully in Pakistan. Research was conducted to study "phonological traits of canola in response to different concentrations of ammonium sulphate foliar spray" at Agronomy Res. Farm, Univ. of Agriculture, Peshawar in season 2014-15. The experiment consists of ammonium sulphate foliar spray concentrations (1\%, $0.2 \%$ and $0.3 \%$ ) and control means water spray in randomized complete block design replicated four times.

Results showed that Number of leaves and number of branches were no significant while the rest phonological traits were affected significantly. Less days to flowering (303), Days to pod formation (350), Days to maturity (469), and more biological yield (3856 kg ha ${ }^{-1}$ ) and grain yield (2360 $\mathrm{kg} \mathrm{ha}^{-1}$ ) were recorded for $1 \%$ foliar application of sulphur. While maximum data were recorded in plots with no foliar spray for (days to flowering, days to pod formation and days to maturity) and less biological and grain yield. Data revealed that foliar application of ammonium sulphate at rate of $1 \% \mathrm{~S}$ was more efficient as compared with control for the phenological traits of canola. From this study, it was concluded that phonological traits were substantially improved by the foliar application of Sulphur @1\%.
\end{abstract}

Keywords: Canola; Amonium Sulphate; Foliar Spra; Phenological traits and Yield

\section{Introduction}

Rapeseed (Brassica napus L.) belongs to the Cruciferae family the common species are Nigra, Carinata, juncea, oleracea and compestries Holmes [1]. Rapeseed or mustard was grown from $300 \mathrm{Bc}$ in Indus valley of Pakistan as a fodder crop. Rapeseed and mustard are traditional oil seed crops of Pakistan are grown in large area of four provinces of country Khan et al. [2] Canola was introduced in Pakistan during 1995 for general cultivation to replace traditional oilseed crops like rapes and mustards because of its low erucic acid contents and high yielding capacity (Chaudhry et al. 2011). During 2011-12 in Pakistan the Canola crop was cultivated 14700 ha with the production of 7000 tones, while Khyber Phukhtunkhwa the area under cultivation was 1300 ha with a total production of 1800 tones MNFSR [3].

Like all other crops, growth, developmental process and grain yield of canola depends upon biotic and abiotic factors. Sulfur is the fourth major plant nutrient after nitrogen, phosphorus and potassium. It is essential for synthesis of the amino acids like cystine, and methionine, a component of vitamin A and activates certain enzyme systems in plants Havlinet al. [4]. It is also an important soil fertility factor to consider when growing canola Ghosh et al. [5] because of high requirement of S by Cruciferae family Scherer [6]. The seed yield, total dry matter and harvest index in some genotypes of Brassica napus and Brassica juncea has been found to improve with higher rate of sulphur Chandel et al. [7] and Malhi et al. [8]. Sulphur deficiency adversely reduces yield, protein and enzyme synthesis Scherer [6]. Sometimes Plant immobility makes the nutrient deficient and S deficiency at any growth stage can cause considerable reduction in seed yield of canola and thus a regular supply of available $S$ is required throughout the growing season Malhi and Gill [9].

Plant nutrients availability at appropriate time and amount is predictable to harvest optimal yields Habtegebrial and Singh (2006). Soil fertility status varies with nature of cropping pattern and management practices. In Pakistan, entire 
available soil is almost nutrient deficient (Anon 2008). Soils are generally deficient in organic matter content reflecting the severe deficiency of nitrogen (almost $100 \%$ ) with phosphorus deficiency in more than 90 percent soils and potassium in 50 percent soils Anon [10]. Micronutrients; zinc, boron and iron are also emerging as deficient. Ahmad and Khan [11] declared that 75-92 percent soils of Pakistan are deficient in organic matter (0-1\%), 70-95 percent in phosphates and 20-60 percent soils in potash. Keep in view the importance of ammonium sulphate present research was conducted in order to study the response of canola to different application of foliar spray on canola the objectives to determine the effects of ammonium sulphate $(1 \%$, $0.2 \%$, and $0.3 \%$ ) foliar application on canola phenology and traits.

\section{Materials and Methods}

The Experiment entitled "Phenological traits of canola in response to different concentrations of ammonium sulphate foliar spray" was conducted at the Palatoo research farm Department of Agronomy, Amir Muhammad khan Campus, Mardan during rabi season 2014-2015. The experiment consists of ammonium sulphate levels $(1 \%, 0.2 \%$ and $0.3 \%)$ and water spray. The experiment was laid out in randomized complete block, having four replications. The plot size was $2 \times 2 \mathrm{~m}^{2}$. Ploughing was done with help of cultivator and crop sown. The basel dose $\mathrm{N}$ and $\mathrm{P}$ @70 and 40kg 1 ha applied respectively. Hoeing was carried out after rosette stage to control weeds. All the agronomic practices were applied according to crop need (Table 1).

Table 1: Phenological traits and yield of canola as affected by ammonium sulphate foliar application.

\begin{tabular}{|c|c|c|c|c|c|c|c|}
\hline $\begin{array}{l}\text { Ammonium } \\
\text { Sulphate }\end{array}$ & $\begin{array}{c}\text { no of leaves } \\
\text { plant-1 }\end{array}$ & no of branches & $\begin{array}{l}\text { Days to pod } \\
\text { formation }\end{array}$ & $\begin{array}{c}\text { Days to } \\
\text { flowering }\end{array}$ & $\begin{array}{l}\text { Days to } \\
\text { maturity }\end{array}$ & $\begin{array}{c}\text { Biological } \\
\text { yield }\end{array}$ & Grain yield \\
\hline $0.20 \%$ & 16 & 16 & 371.5 & 305 & 471.75 & 1568 & 1698 \\
\hline $0.30 \%$ & 16 & 17 & 367.75 & 308.25 & 471.75 & 3233 & 2323 \\
\hline $1 \%$ & 17 & 15 & 350 & 303.5 & 469.5 & 3856 & 2360 \\
\hline Control & 15 & 16 & 372.5 & 309.25 & 484 & 2726 & 2147 \\
\hline
\end{tabular}

\section{Statistical Analysis}

The data recorded was analyzed statistically using analysis of variance techniques appropriate for randomized complete block design. Means were compared using LSD test at 0.05 level of probability, when the F-values were significant Sharifi et al. [12] and Malik et al. [13].

\section{Results and Discussion}

\section{Number of Leaves plant ${ }^{-1}$}

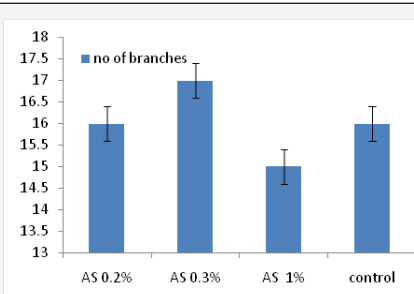

Figure 1: Number of branches of Canola as affected by different levels of ammonium sulphate foliar application

Data regarding number of leaves as influenced by different levels of Ammonium Sulfate foliar spray is presented in (Figure 1). Statistical analysis of the data had showed non-significant effect. However, the number of leaves generally increased with the increasing levels of Ammonium sulfate as foliar spray. The possible reason might be that it is genetically character which cannot be effected by external application of fertilization/ nutrients respectively. As the ammonium sulphate solution was applied to crop in very less concentration, therefore the number of leaves was not significantly affected.

\section{Number of branches plant ${ }^{-1}$}

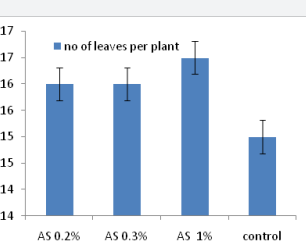

Figure 2: Number of leaves per plant of Canola as affected by different levels of ammonium sulphate foliar application.

Number of branches per plant as influenced by different levels of Ammonium Sulfate foliar spray is presented in (Figure 2). Analysis of the data had showed non-significant effect on branches per plant. However, the number of branches generally increased with the increasing levels of Ammonium sulfate as foliar spray. The possible reason might be that it is genetically character which cannot be effected by external application of fertilization/ nutrients respectively. As the ammonium sulphate solution was applied to crop in very less concentration, therefore the numbers of branches were not significantly affected.

\section{Days to flowering}

Data regarding days to flowering as influenced by different levels of Ammonium Sulfate foliar spray is presented in (Figure 3). Statistical Analysis of the data had showed significant effect on number of days taken to initiation of flowers formation. Maximum days to flower formation initiation (303) were noticed by the application of $1 \%$ foliar application of Ammonium sulfate, 
followed by $0.3 \%$ foliar spray (308) while minimum days to flowering (309) was recorded in plots with no spray. These findings are also in line with Brandt et al. [14].

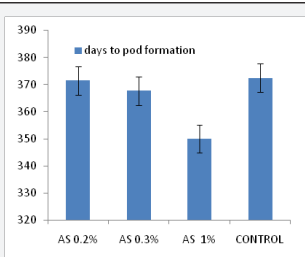

Figure 3: Days to pod formation of Canola as affected by different levels of ammonium sulphate foliar application.

\section{Days to pods formation}

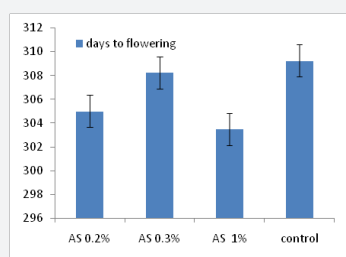

Figure 4: Days to flowering of Canola as affected by different levels of ammonium sulphate foliar application.

Pods formation of canola as influenced by different levels of Ammonium Sulfate foliar spray is presented in (Figure 4). Statistical Analysis of the data had showed significant effect on number of days taken to pods formation. Maximum days to pods formation (350) were recorded by the application of $1 \%$ foliar application of Ammonium sulfate, followed by $0.3 \%$ (367), 0.2 $\%$ (371) while minimum days (372) were recorded in plots with no spray. These findings are also in line with Brandt et al. [14] and Nakhlaway et al. [15].

\section{Days to maturity}

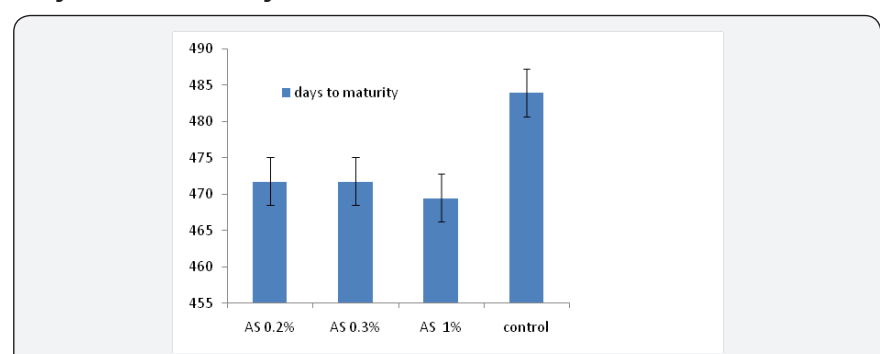

Figure 5: Days to maturity of Canola as affected by different levels of ammonium sulphate foliar application.

Number of days taken from sowing till the maturity of the crop as affected by different levels of Ammonium Sulfate foliar spray is given in (Figure 5). Based on statistical analysis of the data showed a significant effect on number of days taken to crop maturity. Maximum days to maturity (469) were observed for $1 \%$ foliar application of Ammonium sulfate, followed by 0.3 $\%$ (471) which is statistically at par with $0.2 \%$ spray while minimum days to maturity (484) were recorded in plots with no spray. These findings are also in line with Nakhlaway et al. [15] and Cheema et al. [16].

\section{Biological yield ( $\left.\mathrm{kg} \mathrm{ha}^{-1}\right)$}

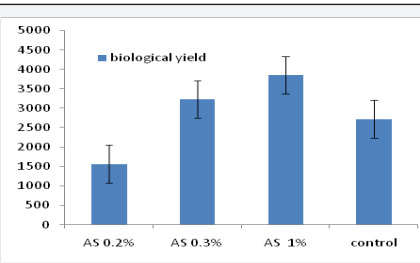

Figure 6: Biological yield $\left(\mathrm{kg} \mathrm{ha}^{-1}\right)$ of Canola as affected by different levels of ammonium sulphate foliar application.

Data regarding on biological yield is presented in (Figure 6). Statistical analysis shows that there is a significant effect on biological yield of canola due to ammonium sulphate foliar application. Maximum biological yield (3856 $\left.\mathrm{kgha}^{-1}\right)$ were obtained with the application of $1 \%$ ammonium sulphate as compare to control (2726 $\mathrm{kgha}^{-1}$ ), $0.2 \%$ (1568 $\mathrm{kgha}^{-1}$ ) and $0.3 \%$ (3233 $\mathrm{kgha}^{-1}$ ) solution. The result are in line with the findings of Malik et al. [13] and Jan et al. [17] and Sattar et al. [18] who found that from higher rate of sulphur application more biological yield can be obtained [19-25].

\section{Grain yield $\left(\mathrm{kg} \mathrm{ha}^{-1}\right)$}

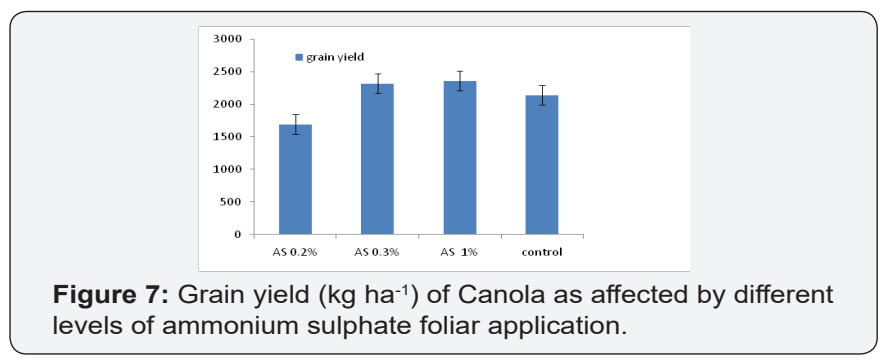

Grain yield kg ha- 1 of canola as affected by ammonium sulfate foliar spray is presented in (Figure 7). Statistical analysis shows that there is a significant affect in grain yield due to ammonium sulphate foliar application on canola [26]. More grain yield (2360 $\mathrm{kgha}^{-1}$ ) were obtained with the application of $1 \%$ ammonium sulphate as compare to control (2147 kgha-1), 0.2\% (1700 kgha $\left.{ }^{1}\right)$ and $0.3 \%\left(2323 \mathrm{kgha}^{-1}\right)$ solution [27-29]. The result is also in agreement with the findings of Sharifi [12] who reported that increasing levels of sulphur solution increased grains yield of canola which is an oil seed crop, respond positively to sulphur application due to which its grain yield increases Malik et al. [13].

\section{Conclusion and Recommendation}

From this experiment it was concluded that number of leaves and branches were not affected by ammonium sulphate foliar spray while less days to flowering (303), days to pod formation (350), days to maturity (469), more biological yield (3856 $\mathrm{kg} \mathrm{ha}^{-1}$ ) and grain yield (2360 $\mathrm{kg} \mathrm{ha}^{-1}$ ) were recorded for $1 \%$ foliar application of sulphur. On the basis of current research it is recommended that ammonium sulphate @ 1\% foliar spray is optimum for achieving phenological attributes and yield of canola. 


\section{References}

1. Holmes MRJ (1980) In Nutrition of the oilseed rape crop. Nitrogen, Applied sci PubBarking Essex, England p. 21-67.

2. Khan AH, IA Khalil, H Shah (2004) Nutritional yield and oil quality of canola cultivars grown in NWFP. Sarhad J Agric 20(2): 287-290.

3. MNFSR (2012) The Statistics Government Of Pakistan Ministry Of Food Security And Research Islamabad, Pakistan.

4. Havlin JL, JD Beaton, SL Tisdale, WL Nelson (2004) Soil fertility and fertilizers. An introduction to nutrient management. (7th Edn), Pearson Education Inc, Singapore, pp. 221.

5. Ghosh PK, KM Hati, KG Mandal, AK Misra, RS Chaudhary, et al. (2000) Sulphur nutrition in oilseeds and oilseeds-based cropping systems. Fert Newsl 8(45): 51-52.

6. Scherer HW (2001) Sulphur in crop production. Eur J Agron 14(2): 81111.

7. Chandel RS, Sudhakar PC, Singh K (2002) Direct and residual effect of sulphur on Indian mustard (Brassica juncea L) in rice (Oriza sativa L) Indian mustard cropping system. Ind J Agric Sci 72: 230-232.

8. Malhi S, Gan Y, Raney J (2007) Yield, seed quality and sulphur uptake of brassica oil seed cropsin response to sulphur fertilization. Agron J 99(2): 570-577.

9. Malhi SS, Gill KS (2002) Effectiveness of sulphate-S fertilization at different growth stages for yield, seed quality and S uptake of canola. Can J Plant Sci 82: 665-674.

10. Anon (2008) Fertilizer use efficiency and crop productivity: where we stand and what should be done (Panel discussion). Proc Symp "Balanced Fertilizer Use: Impact on Crop Production". NFDC, Islamabad, Pakistan.

11. Ahmad N, AA Khan (2006) Nutrient management for sustainable agriculture in Pakistan. In: Poster Session. IFA Conference "Optimizing Resource Use Efficiency for Sustainable Intensification of Agriculture". Kunming, China.

12. Sharifi RS (2012) sulphur fertilizer effects on grain yield and the sum of physiological indices of canola (brassica napus)L. Annals of biological research 3(11): 5034-5041.

13. Malik MA, I Aziz, HZ Khan, MA Wahid (2004) Growth, Seed Yield and Oil content response of Canola (Vrassicanapus L.)to Varying levels of sulphur. Int J Agri Biol 6(6): 1153-1155.

14. Brandt SA, Malhi SS, Ulrich D, Lafond GP, Kutcher HR, et al. (2007) Seeding rate, fertiliser level and disease management effects on hybrid versus open pollinated canola (Brassica napus L). Can J Plant Sci 87(2): 255-266.

15. El Nakhlawy FS, Bakhashwain AA (2009) Performance of canola (Brassica napus L.) seed yield, yield components and seed quality under the effects of four genotypes and nitrogen fertiliser rates. Met Env Arid Land Agric Sci 20(2): 33-47.

This work is licensed under Creative

Commons Attribution 4.0 Licens

DOI: 10.19080/IJESNR.2017.02.555584
16. Cheema MA, Malik MA, Hussain A, Shah SH, Basra SMA (2001) Effects of time and rate of nitrogen and phosphorus application on the growth and the seed and oil yields of canola (Brassica napus L). J Agron Crop Sci 186(2): 103-110.

17. Jan A, G Ahmad, T Jan, M Jamaland, F Subhan (2008) Oil yields of Canola as affected by $\mathrm{N}$ and $\mathrm{S}$ levels and methods of application under rainfed conditions. Sarhad J Agric 24(1).

18. Sattar A, MA Cheema, MA Wahid, MF Saleem, M Hassan (2011) Interactive effect of sulphur and nitrogen on growth, yield and quality of canola. Crop Environ 2: 32-37.

19. Anon (2009) Data on area, yield and production of major Rabi and kharif crops. Personal Communication, District Officer, Extension Wing, Agriculture Department, Attock, Pakistan.

20. Aulakh MS (2003) Crop response to sulfur nutrition. In: YP Abrol and A Ahmad (Eds), Sulfur in Plants. Kluwer Academic Publications, Dordrecht, Netherlands, Europe, PP. 341-354.

21. Fisme J, PC Vong, A Guckert, E Frossard (2000) Influence of sulphur on apparent $\mathrm{N}$-use efficiency, yield and quality of oilseed rape (Brassica napus L) grown on a calcareous soil. European Journal of Agronomy 12(2): 127-141.

22. Jamal A, YS Moon, MZ Abdin (2010) Sulphur A general overview and interaction with nitrogen. Aust J Crop Sci 4(7): 523-529.

23. Khalid R, KS Khan, M Yousaf, G Shabbir, A Subhani (2009) Effect of sulfur fertilization on rapeseed and plant available sulfur in soils of Pothwar, Pakistan. Sarhad J Agric 25(1): 65-71.

24. Mirzashahi k, M Pishdaradanegi, F Nourgholipour (2009) Effects Different Rates of Nitrogen and Sulphur Application on Canola Yield in North of Khuzestan. Journal of Research in Agricultural Science 6(2): $107-112$.

25. Rehman UH, Q Iqbal, M Farooq, I Afzal, SMA Basra (2013) Sulphur application improves the growth, seed yield and oil quality of canola. Acta Physiologiae Plantarum 35(10): 2999-3006.

26. Wang X, WB Hoogmoed, D Cai, UD Perdok, O Oenema (2007) Crop residue, manure and fertilizer in dryland maize under reduced tillage in northern China: IInutrient balances and soil fertility. Nutr Cycl Agroecosys 79(1): 17-34.

27. Yadav HK, T Thomas, V Khajuria (2010) Effect of different levels of sulphur and biofertilizer on the yield of Indian mustard (Brassica juncea L) and soil properties. Journal of Agricultural Physics 10: 61-65.

28. Zhao FJ, SP McGrath, MM A Blake Kalff, A Link, M Tucker (2002) Crop responses to sulfur fertilization in Europe. Proc Int Fert Soc Cambridge, UK, 504: 27.

29. Vaseghi S, valinejad M, Afazali M (2011) yield, seed quality and sulphur uptake of brassica oilseed crops in response to sulphur fertilization. World of science journal 1:163-172.

\begin{tabular}{l} 
Your next submission with JuniperPublishers \\
will reach you the below assets \\
- Quality Editorial service \\
- Swift Peer Review \\
- Reprints availability \\
- E-prints Service \\
- Manuscript Podcast for convenient understanding \\
- Global attainment for your research \\
- Manuscript accessibility in different formats \\
( Pdf, E-pub, Full Text, audio) \\
- Unceasing customer service \\
Track the below URL for one-step submission \\
https://juniperpublishers.com/online-submission.php \\
\hline
\end{tabular}

